\title{
What's in a name? \\ A history of New Zealand's unique name suppression laws and their impact on press freedom
}

\begin{abstract}
The principle of open justice, including the media's right to attend and report on criminal courts, must be balanced with the protection of individuals' privacy and an accused person's fair trial rights. Prohibiting media from identifying those involved in criminal cases is one way privacy and fair trial rights may be protected in New Zealand. Court news was not always restricted in this way: 115 years ago all parts of criminal court proceedings could be reported and media decided what information was censored. In 1905, New Zealand judges were given the power to suppress court evidence to protect public morality, and 15 years later, the power to suppress the names of certain first offenders to give them a second chance. The laws now stretch to suppressing many kinds of evidence and the identities of some people accused and convicted of New Zealand's most serious crimes. Investigation of the 115-year-long evolution of New Zealand's name suppression laws illuminates a piecemeal, but severe, curtailment of media freedom and a trend of imposition of increasingly complex laws which journalists must keep abreast of, understand and observe to prevent appearing before the courts themselves.
\end{abstract}

Keywords: court reporting, contempt of court, crime reporting, fair trial rights, media law, name suppression, New Zealand, press freedom, privacy, open justice

\section{FRANCINE TYLER}

Massey University, Wellington

\section{Introduction}

HE PRINCIPLE of open justice, maintaining that justice should be transparent and open to the public, has been entrenched in British law for centuries (Davis, 2001; Pearson \& Graham, 2010). New Zealand has firmly adopted the principle of open justice and, in most cases, allows media to be present and report in the criminal courts as public representatives (Buckingham, 2011; Patel, 2018). The media's role in court reporting is vital to the open justice principle by informing the public broadly about the operation of the judicial system (Pearson \& Graham, 2010). The media's right to report on criminal court 
proceedings is supported by the New Zealand Bill of Rights Act 1990 (NZBORA) which stipulates that 'everyone has the right to ... seek, receive, and impart information and opinions of any kind in any form' (NZBORA, s 14). In criminal court cases, however, name suppression orders may prevent media from identifying some people.

In New Zealand, name suppression is codified in legislation and either automatically applied or granted at judicial discretion. Name suppression has been controversial in New Zealand since it was introduced in the Offenders Probation Act 1920. Since then, academics, lawmakers and the judiciary have debated two broadly opposing interests involved with name suppression: individuals' rights versus the principles of open justice (Davis, 2001; Jones, 1995; Patel, 2018; Pearson \& Graham, 2010). On one hand, naming the accused may encourage participation of further witnesses or victims (Davis, 2001; Pearson \& Graham, 2010), be considered part of the punishment for offending, and deter reoffending (Jones, 1995). On the other hand, identifying the accused may damage reputations and/or cause distress and embarrassment (Pearson \& Graham, 2010), and remove the presumption of innocence and thus destroy fair trial rights (Davis, 2001). Fair trial rights are also enshrined in NZBORA which states everyone has 'the right to a fair and public hearing by an independent and impartial court' (NZBORA, $\mathrm{s}$ 25(a)). The words 'fair' and 'public' in section 25(a) aptly illustrate the conflict between the concepts of fair trial rights and the public's right to know. Despite the importance placed on open justice in New Zealand, the most recent Justice Ministry figures show that in 2018/19 permanent name suppression was granted to 315 people, of whom 56 percent $(n=176)$ were convicted and 18 percent $(n=56)$ were imprisoned (Ministry of Justice, 2020). The names of those 315 people will never be allowed to be published in relation to those crimes, even after they have died, unless a court rescinds suppression. New Zealand's more than 100-year journey to today's name suppression laws has steadily restricted press freedom in reporting on criminal courts. Little has been written about the controversy that has surrounded New Zealand's name suppression journey, the exclusion of media representatives from Parliamentary discussion over the formulation of the relevant legislation, or the arguable erosion of press freedom.

\section{New Zealand's suppression journey}

New Zealand's first legislation allowing suppression of criminal court evidence aimed to protect public morality and followed public outrage over unsavoury details published in newspapers about a man who impregnated a 15 -year-old employee and escaped prosecution after she died during childbirth (A man's iniquity, 1905). The Criminal Code Amendment Bill 1905, as then Justice Minister James McGowan told the House, aimed to protect under 21-year-olds from exposure to morally corrupting information and prevent media reports 'not of 
an edifying character' (McGowan, 1905, p. 238). Member of Parliament (MP) Charles Lewis had unsuccessfully argued for inclusion of name suppression in the bill, stating an acquitted person may be 'damned for his lifetime because of what occurred' (Lewis, 1905, p. 239). It appears from the Hansard transcript that although judges were consulted over the bill, the media was not (McGowan, 1905). Certain quarters of the media expressed outrage. The Lyttelton Times presciently warned the legislation would be the 'first step to establishing a Press censorship in New Zealand' (The Criminal Code Amendment Bill, 1905). Hansard also showed some MPs disagreed with publication prohibitions, as newspapers generally complied with judicial requests not to publish details (McLean, 1905). However, the 1905 launch of the tabloid-style New Zealand Truth newspaper, noted for its 'muck-raking' (Papers Past, 2020), may have hardened some MPs' opinions on media trustworthiness. MP John Jenkins described the newspaper as 'one of the vilest productions that ever issued from the printing press' after it published evidence from an upcoming court case (Jenkins, 1905)(1). The Act, enacted on August 30, 1905, allowed judges to clear the court (to protect public morality) of everyone except the prosecutor, defence lawyer, accused, and, in a late addition, the media, and also to order certain evidence be suppressed from publication (Criminal Code Amendment Act 1905, ss 3 \& 4). Recurring themes were beginning to emerge in the progression of suppression legislation-wilful antagonism toward media expressed by some MPs, and discounting of media interests and their potential to be sound moral agents.

Prior to 1920, the media held the sole right to determine whose names were published in criminal court news. An informal agreement between most major newspapers stipulated that all accused persons would be named except for first offenders of drunkenness, children under 15 years in Juvenile Court, and debtors who successfully argued against imprisonment for unpaid debts (A flaw in the law, 1920). This all changed when, at the request of probation officers seeking to give young, first offenders a second chance, Justice Minister Ernest Lee included provision in the Offenders Probation Bill 1920 giving judiciary the power to suppress names of first offenders eligible for probation (Lee, 1920). In response, one newspaper editor warned that suppressing names of offenders would, 'arouse in the public mind such suspicions ... that there is one law for the rich and another for the poor' (Very inadvisable, 1920). The Offenders Probation Act 1920 passed on October 28 that year. Some newspaper editors were vociferously opposed to the legislation. One described the law as a 'hush-hush policy' and warned that not naming 'thieves and other lawbreakers' would 'undoubtedly encourage crime' (The 'hush-hush' policy, 1920). The editor continued, 'It is certainly time that the newspapers of the Dominion combined to protect their rights, which are gradually being filched from them' (ibid.). One of the earliest name suppression 
applications, on 24 November 1920, involved a 16-year-old girl who stole a wristwatch (The courts today, 1920). The magistrate declined name suppression saying he would instead just request that newspapers not name her (ibid.); newspapers did not publish her name. Name suppression was, however, granted on 21 December 1920 to mother-and-daughter first offenders who twice stole hats from a milliner (Not for publication, 1920). It appears that media, despite being upset with the new judicial powers, continued to cooperate with requests not to publish and also complied with name suppression orders; however, from the outset judicial application of the law was inconsistent.

Little advice had been provided to the judiciary about the application of name suppression (Local and General, 1921a). Magistrate Robert Dyer, in remarking that too many name suppression requests were being made, noted, 'A law has been passed giving Magistrates the right to order the suppression of names, but on what basis we are to act I do not know' (ibid.). Confusion about the practicalities of name suppression led some judges to set inconsistent boundaries. Magistrate Joseph Poynton declared: 'The names will not be suppressed unless the offender is under 21 years, and is a first offender' (Auckland Star, 1921). Two months later, Magistrate Samuel McCarthy took a narrower stance stating, 'Mr Poynton has decided not to extend this provision of the non-publication of names to any over the age of twenty one, or beyond the first offence. In my opinion, that is too wide. I intend to confine it to juveniles under the age of sixteen' (Local and General, 1921b). Newspapers were also inconsistent in publication of names. In one 1923 case, despite a judge explicitly requesting publication of the name of a convicted sex offender, the newspaper did not print his name (Grossly indecent act, 1923). The Waikato Times stated in an editorial that publication of names was the greatest deterrent to crime and congratulated one magistrate for refusing to suppress the name of a man charged with being drunk and disorderly; however, it did not name the accused (Day by day, 1924). NZ Truth, one of the greatest critics of name suppression, in 1925 did not identify a woman convicted of stealing money from her employer, despite describing her lawyer's unsuccessful name suppression request as 'monumental cheek' (Quite pardonable difference, 1925). The media's failure to name some criminals, even in cases when judges allowed or recommended it, may indicate some editors' growing discontent with the new laws and may have amounted to a protest against having to follow the courts' rulings.

The media won a victory against the limitation of their freedoms in 1929 when MP Rex Mason failed in a bid to introduce compulsory name suppression for almost all first offenders, (Offenders Probation Amendment Bill, 1929). The victory, however, was only won with the support of business groups (Local and General, 1929), and was only temporary. The following year name suppression was extended to include publication of 'any other name or particulars likely to lead to the identification of such person' (Offenders Probation Amendment Act 
1930, s 2(2)). Justice Minister John Cobbe told the House some newspapers had published enough detail to easily identify persons granted name suppression (Cobbe, 1930). The Act made it contempt of court to breach name suppression, with a maximum fine of 100 pounds (Offenders Probation Act 1930, s 2(3)). The inclusion of identifying particulars to name suppression increased potential for a breach if media inadvertently published too much information. It also meant that if media felt suppression was unjustified they could no longer simply circumvent it by giving hints to identity. In just ten years, the media's right to determine what information was published in court stories, had been seriously undermined. If editors retaliated by ignoring suppression orders they believed unjustified they faced being found in contempt of court and fines which could financially ruin them.

The original intent of name suppression, to protect identities of first offenders, changed significantly in 1954 when eligibility was extended to include those accused or convicted of any crime as long as they had no previous convictions for imprisonable offences (Criminal Justice Act 1954). Initially, Justice Minister Clifton Webb had intended name suppression to cover all people who appeared in court, but after media argued such broad suppression was against the public interest, agreed to reduce the scope (Webb, 1954). Despite Webb's concession, antagonism towards the media's position was again evident when MP John Stewart described the media's response as 'exaggerated as usual' (Stewart, 1954, p. 1941). He accused newspapers of scaremongering by falsely claiming trials would be held in secret and stated newspapers had abused their privilege by suppressing the identities of prominent figures and newspaper controllers' friends while ruthlessly exposing the names of those they did not like (ibid.). Stewart's claim, made without any supporting evidence, reveals a degree of enmity that likely shaped some lawmakers' decisions about restricting media freedoms.

In 1967 MPs finally fulfilled the wishes of some of their earlier counterparts and extended, at the request of the Law Society (Hanan, 1967), name suppression eligibility to all offenders (Criminal Justice Amendment Act 1967, s 9). Justice Minister Ralph Hanan's statement to the House indicated that, while all would be eligible for name suppression, it should be infrequently used (Hanan, 1967). Hanan described, in example, the possibility of revealing an incest victim's identity because the accused was ineligible for name suppression (ibid.). The contention that MPs intended only occasional use of name suppression is supported by a statement made by MP Dr Martyn Findlay, who said while name suppression should be allowed for everyone, it should be used sparingly (Findlay, 1967). Name suppression laws were again to extended in 1969 to allow accused persons to apply for temporary, or interim, name suppression (Criminal Justice Amendment Act, 1969).

In 1975, a legislative change that automatically suppressed the names of every accused person, up until their case was concluded, brought media and MPs 
to loggerheads. The change, a recommendation by the Criminal Law Reform Committee (CLRC), made up of the Solicitor General, law professionals, and representatives from government departments and universities, was the greatest alteration to reporting court news in New Zealand's history (Eckersley, 2016; NZ move to suppress accused's name, 1975). Government had initially intended automatic name suppression only for victims of sexual offences aged under 16 years and those charged and/or convicted of incest with a child under 16 (Findlay, 1974). When the bill returned for its second reading, however, the new clause had been added to automatically suppress the identities of all defendants up until conviction, unless the court ordered differently (Eckersley, 2016). Name suppression could be lifted if the accused requested it, or if any member of the public felt they or their family would be prejudiced if an accused's name was not revealed (Criminal Justice Amendment Bill 1975, cl 14).

The proposal was opposed by not only media, but also a number of lawyers (NZ move to suppress accused's name, 1975). Journalists claimed the proposed law meant that 'no effective and sustained reporting of the case is possible' and it would result in court news stories becoming mere lists of guilty parties (ibid.). Thirty-two public submissions were made on the bill, ten from media organisations or journalists, and all ten expressed opposition (Stace, 1976). The Press Council president warned of the dangers of secret trials; the editor of The Sunday News defended the public's right to know about criminal matters; and journalists claimed court reports would be made confusing and dull (ibid.). The police commissioner, two other organisations representing police and the New Zealand Law Society also opposed the blanket suppression law (ibid.). Nonetheless, the Criminal Justice Amendment Act (No.2) 1975 passed on September 19.

Blanket suppression lasted only 10 months. During its time of enforcement, MPs were suddenly exposed to one of its negative consequences when fellow MP Gerald O'Brien was charged with molesting two boys (Gay, 2019). Reports of O'Brien's arrest, which could not include his name because of the suppression law, saw several other male MPs approach the media to declare the accused person was not them (ibid). The governing Labour Party was ousted at the 1975 general election and the new National Party government repealed the automatic suppression-for-all law, on 29 July 1976, returning the law to the 1967 position where name suppression was available to all but only by order of a judge (Criminal Justice Amendment Act 1976, s 2(1)). The 1976 act retained automatic suppression of names in specified sexual offences introduced by the repealed 1975 act (ibid, ss $2 \& 3$ ).

Further extensions of name suppression were to follow in subsequent years. Automatic name suppression was extended to: members of the New Zealand Security Intelligence Service (except the director), and anyone connected with them (New Zealand Security Intelligence Service Amendment Act 1977); and 
all victims of sexual offending (Criminal Justice Amendment Act 1980, s 23). Each extension of name suppression legislation meant further erosion to press freedom, and an ever-growing and complex number of situations where media might inadvertently breach an order, particularly when these were automatic and not vocalised in court by the judge.

In 1982, for the first time, media could be ordered to leave the court during closed court hearings, but only in the interests of national security or defence (Crimes Amendment Act 1982, s 4(1)). The legislation did not give journalists the right to challenge an order to leave court and, as the hearing was closed, they could not subsequently determine whether the order was justified.

Extension after extension to name suppression continued over subsequent years, each making the laws more complex and each concealing further information from the public. In 1985 judges were given power to suppress the names and identifying particulars of witnesses and any evidence given during times when the court was closed and also any person's address and occupation (Criminal Justice Act 1985, ss 138 \& 140). Additionally, a different act prohibited disclosure in open court of the names and addresses of victims of, and parties to sexual violation-related crimes; inducing sexual connection by coercion; and compelling another to do an indecent act with an animal, effectively suppressing these from publication by media (Evidence Amendment Act (No. 2) 1985, s 23AA). In 1986 , undercover police officers were also granted a form of anonymity when, in giving court evidence in serious or most drug-related crimes, they were allowed to use the fictitious names used during the investigation (Evidence Amendment Act 1986, s 2; Summary Proceedings Amendment Act 1986, s 4). In 1989, automatic name suppression was extended to cover witnesses aged under 17 years in criminal cases (Children, Young Persons and Their Families Act 1989, s 454). In 1995, those ordered to submit a sample for DNA testing were also granted automatic name suppression unless they were charged with an offence relating to the reason for the test (Criminal Investigations (Blood Samples) Act 1995, s 14). The Evidence (Witness Anonymity) Amendment Act 1997 allowed some witnesses in serious criminal trials to be identified only as 'Witness A' or another initial (ibid., s 3). A breach of witness anonymity attracted much harsher punishment than other suppression breaches: a maximum of seven years in prison for a deliberate breach, and maximum fines of $\$ 2000$ for individuals or $\$ 10,000$ for bodies corporate for an accidental breach (ibid.). One difficulty in witness anonymity was that mandated anonymity included a witness's address, occupation and other identifying particulars (ibid.) making it sometimes difficult for journalists to write about the witness without inadvertently revealing too much information. The need to give context to witnesses, while also avoiding breaching anonymity, and potential harsh penalties, added considerable complexity to reporting such cases. 
Inconsistencies in the application of name suppression and concern over erosion of open justice and press freedom led to a major review of suppression laws in 2008 (New Zealand Law Commission, 2008). Some review submitters stated name suppression had become so common it was granted on first appearance 'almost as a matter of course' (New Zealand Law Commission, 2009, p. 18). Prominent people were also more likely to be given name suppression, some claimed (ibid). The commission made 35 recommendations to government (ibid.), many of which were included in the subsequent Criminal Procedure Act 2011 , including a guide for judges on grounds for granting name suppressions. The guide included consideration that refusal would: cause 'extreme hardship' to the defendant or others; cast suspicion on others; endanger any person; identify another person whose name is suppressed; risk ongoing, or other, investigations; prejudice the security or defence of the nation; and create a real risk of prejudicing a fair trial (Criminal Procedure Act 2011, s 200 (2)). The act also stipulated that a defendant being well-known did not constitute 'extreme hardship' (ibid., s 200 (3)). In 2011, for the first time, the media was granted the right to challenge name suppression orders in court (ibid, s 210). This was a significant development acknowledging the media was a party to proceedings, and giving journalists the right to stand up in court and oppose a name suppression order. However, some journalists lacked the experience, confidence and legal skills to present a compelling case. The legislation also required judges to provide reasons for granting name suppression; however, the reasons themselves could also be suppressed in exceptional circumstances (ibid., s 207). In some cases, suppression of reasons for suppression has placed the onus on media to explain why open justice principles cannot be upheld (Hurley, 2019). The 2011 act also granted automatic name suppression to victims in criminal cases aged under 18 years, unless they were dead, and increased the age for automatic suppression for witnesses by one year to cover those aged under 18 years (Criminal Procedure Act, 2011, s 204).

\section{Juvenile offenders}

Some of the most stringent of New Zealand's suppression laws relate to children and young offenders. Special Children's Court sessions were introduced in 1906 for offenders aged under 16 years, and, while hearings could be closed to the public, reporters could remain and publish all details of the cases (Juvenile Offenders Act 1906). Automatic name suppression for offenders aged under 16 years, their parents or guardians and any other name which could identify the child was introduced in Children's Court in 1925, with journalists having to seek permission to be present and to publish stories (Child Welfare Act 1925, s 30(2)). The age for being considered a juvenile offender was increased in 1927 to those aged under 17 years (Child Welfare Amendment Act 1927, ss 22 \& 27). 
In 1974, automatic suppressions in the renamed Youth Court were extended to include the name of the accused's school (Children and Young Persons Act 1974, s 24). In 1982, automatic suppressions were removed for youths aged 15 years or over sentenced as an adult in a District Court for serious crimes (Children and Young Persons Amendment Act 1982, s 6). Youth Court automatic suppressions were again extended in 1989 to include the names of victims (Children, Young Persons and Their Families Act 1989, s 329). The strict suppression laws for young offenders echo the calls of those 1920 probation officers who justifiably fought for a second chance for young people; however, complexities of reporting proceedings and these strict laws have resulted in much of the Youth Courts' work going unreported.

\section{Other suppressions}

In addition to the automatic and discretionary name suppressions outlined above for criminal courts, there are numerous other suppressions which add complexity for journalists and many more possibilities for accidental suppression breaches. These include suppressions around bail hearings; questions disallowed by a judge; anything said in court while the jury is not present; Family Court proceedings; and tribunal hearings (Cheer, 2015). While many of these suppressions have valid reasons, they are also arguably symptomatic of growing and wide-ranging restrictions on press freedom.

\section{Where to from here}

The new Contempt of Court Act 2019, expected to come into effect on $26 \mathrm{Au}-$ gust 2020, has codified some legal constraints and made some laws clearer for journalists working in criminal courts. The Act has, however, added other problems by codifying the ability for judges to order media to remove from websites stories that might prejudice a fair trial. A timeframe has been stipulated for the sub judice period, the time in which information that poses a 'real risk' to a fair trial cannot be published (Contempt of Court Act 2019, s 7). Under the new act the $s u b$ judice period is codified, for serious offences, as being from the time of arrest or charge, whichever happens first, through to: a guilty plea or jury verdict; when a charge is withdrawn or dismissed; or the start of a judge alone trial (ibid.). Previously, sub judice applied from the imprecise time of 'when an arrest was imminent', and while 'time of arrest or charge' is more concrete, journalists are generally reliant on this information being provided by authorities. Information which poses a 'real risk' to a fair trial is also defined in the act, meaning journalists have a list to refer to rather than relying on previous case law (ibid., s 8). Another major change is the codification of takedown orders relating to stories which include a defendant's previous convictions or information that might risk a fair trial (ibid.). While takedown orders only apply to the 
sub judice period, the possibility is raised that once the information is removed, it may not be reinstated due to cost and time constraints, resulting in a de facto kind of lasting censorship. While takedown orders for online news websites have been granted in recent years, these have been limited. It is possible that enshrining the option of takedown orders in legislation could see lawyers seeking these much more frequently with a consequent rise in the number of these orders served on news media. So far there has been little reaction from media to the new act, arguably because it has yet to come into effect so the implications have not been tested.

\section{International context}

In comparison to the straightened New Zealand context, Australia has no bill of rights founded protection of freedom of speech or a public and fair trial (Pearson, 2010). Name suppression is available in Australian courts; however, practices vary considerably across the country's nine states and territories (Pearson, 2010) and are unequally applied. Ackland (2018) reports in the 49 weeks to 8 December 2018 a total of 703 name suppression orders were made, the greatest number in Victoria (301) and the lowest in Tasmania, Australian Capital Territory and Western Australia (1 each). Australia's states have numerous and varying provisions for suppression orders although in all, names of victims of sexual offences and child defendants are automatically protected. These legislative differences pose problems for journalists whose publications cross state boundaries (Pearson, 2010).

The United Kingdom's name suppression regime is a mixture of common and statutory law. Judges may order the names of participants in criminal cases not be used in open court if there is a real risk to the administration of justice, and, thus, these names cannot be published (Judicial College, 2016). Judges also have discretion to suppress the names of certain people involved in criminal proceedings. Automatic name suppressions apply to victims of sexual offences and children involved in Youth Court proceedings (except in cases involving breach of an Anti-Social Behaviour Order). Defendants in criminal trials must be named except in rare circumstances (ibid.). Courts may also order a postponement of publication of reports of proceedings if there is a significant risk to the administration of justice (ibid.). Postponement orders are not intended to permanently prevent publication (Crown Prosecution Service, 2018).

In Canada, freedom of expression is protected by the Canadian Charter of Rights and Freedoms. Canada has a number of statutory suppressions, called publication bans, few of which are automatic (Canadian Judicial Council, 2007). Automatic, permanent suppression is given to victims of, and witnesses to, sex-related crimes, and young people aged under 17 in the Youth Court, except if they are sentenced as an adult (ibid.). Reihle (1996) states free expression 
is often restricted by the scope and extent of publication bans. Similarly, the Canadian Journalists for Free Expression organisation argues that publication bans are too broadly and frequently used and stifle public discussion about the justice system (Metcalfe, 2018).

In the United States of America, the media's right to report in the courts is protected by the First Amendment of the Constitution, which enshrines press freedom. According to Brandwood (2017), American judges have few options for preventing publication of court proceedings. Judges have the ability to issue gag orders preventing lawyers and others involved in cases from speaking to the media and, if they believe publicity may risk a person's fair trial rights, they may order a trial be held in another venue. Brandwood (2017) suggests that in the USA some accused persons do not get a fair trial due to unrestrained publicity. This poses an extreme contrast to the situation in New Zealand.

\section{Conclusion}

The development of New Zealand's name suppression laws are disquieting on a number of fronts. At the beginning of last century, New Zealand's media were entrusted with deciding what information was or was not published from criminal court hearings in the public interest, but over the past 115 years that freedom has steadily been eroded. The initial intent of suppression was to protect public morality, then turned to also give young first offenders a second chance. The practice of name suppression has ballooned to now offer anonymity to those accused, or convicted, of a wide range of crimes, and others involved in court cases. While some name suppressions are warranted, particularly for the protection of victims of sex-related crimes and young people, other measures appear to have been developed by politicians through an unfounded but longstanding mistrust and enmity towards the media.

Media were for decades excluded from any formal discussion of, or contribution to, the early legislative development of New Zealand's name suppression laws, which effectively, without consultation, eroded the media's freedom and right to determine which information was in the public interest. The continued development and extension of name suppression laws has seen them become increasingly complex and disjointed. For example, several acts include automatic name suppressions that apply to rare situations, creating pitfalls into which even seasoned journalists, without the benefit of specialist court knowledge, could easily stumble. The most recent legislative moves have solved some of the problems of interpreting a small area of suppression-related legislation, but other problems still loom large. The effect of the raft of court-ordered and codified name suppressions is the restriction of New Zealand's media in a way that is extremely unusual in comparison to other Western nations. 


\section{Notes}

1. Unfortunately, no 1905 copies of Truth exist in any library so what exactly incensed Jenkins cannot be read.

\section{Hansard}

Cobbe, J. (1930). Offenders Probation Amendment Bill. New Zealand Parliamentary Debates, 226, 220-222.

Findlay, A. M. (1967). Criminal Justice Amendment Bill. New Zealand Parliamentary Debates, 353, 3628-3638.

Findlay. A. M. (1974) Criminal Justice Amendment Bill. New Zealand Parliamentary Debates, 394, 4467-4471.

Hanan, J. R. (1967). Criminal Justice Amendment Bill. New Zealand Parliamentary Debates, 352, 2924-2926.

Jenkins, J. (1905). Criminal Code Amendment Bill. New Zealand Parliamentary Debates, $132,580-584$.

Lee, E. (1920). Offenders Probation Bill. New Zealand Parliamentary Debates, 188, 359-362.

Lewis, C. (1905). Criminal Code Amendment Bill. New Zealand Parliamentary Debates, 132, 238-239.

McGowan, J. (1905). Criminal Code Amendment Bill. New Zealand Parliamentary Debates, 132, 238-239.

McLean, G. (1905). Criminal Code Amendment Bill. New Zealand Parliamentary Debates, 132, 580-584.

Stewart, J. (1954). Criminal Justice Bill. New Zealand Parliamentary Debates, 304, 1925-1942.

Webb, C. (1954). Criminal Justice Bill. New Zealand Parliamentary Debates, 304, 1925-1942.

\section{Legislation}

Child Welfare Act 1925.

Child Welfare Amendment Act 1927.

Children and Young Persons Act 1974.

Children and Young Persons Amendment Act 1982.

Children, Young Persons and Their Families Act 1989. (Renamed Oranga Tamariki Act 1989.)

Contempt of Court Act 2019.

Crimes Amendment Act (No.2) 1982.

Criminal Code Amendment Act 1905.

Criminal Code Amendment Bill 1905.

Criminal Investigations (Blood Samples) Act 1995.

Criminal Justice Act 1954.

Criminal Justice Act 1985.

Criminal Justice Amendment Act 1967.

Criminal Justice Amendment Act 1969.

Criminal Justice Amendment Act (No. 2) 1975.

Criminal Justice Amendment Act 1976. 
Criminal Justice Amendment Act 1980.

Criminal Justice Amendment Bill 1975.

Criminal Procedure Act 2011.

Evidence Amendment Act (No. 2) 1985.

Evidence Amendment Act 1986.

Evidence (Witness Anonymity) Amendment Act 1997.

Judicial Proceedings (regulations of reports) Bill 1935.

Juvenile Offenders Act 1906.

New Zealand Bill of Rights Act 1990.

New Zealand Security Intelligence Service Amendment Act 1977.

Offenders Probation Act 1920.

Offenders Probation Amendment Act 1930.

Offenders Probation Amendment Bill 1929

Offenders Probation Bill 1920.

Summary Proceedings Amendment Act, No. 76. (1986).

\section{Newspapers}

A flaw in the law (1920, December 22). Lyttleton Times, p. 6.

A man's iniquity (1905, May 18). Lyttelton Times, p. 7.

Attack on the press (1937, April 5). New Zealand Herald, p. 8.

Day by day (1924, May 30). Waikato Times, p. 6.

Auckland Star (1921, March 24). Auckland Star, p. 4.

Editorial (1921, January 4). Press, p. 6.

Gay, E. (2019, November 3). Name suppression: How the uniquely Kiwi 'hush hush policy' became law and morphed over a century. Sunday Star-Times, p. 27. Retrieved from https://www.stuff.co.nz/national/crime/117058919/name-suppression-how-theuniquely-kiwi-hush-hush-policy-became-law-and-morphed-over-a-century

Grossly indecent act (1923, October 22). Poverty Bay Herald, p. 5.

Hurley, S. (2019, November 25). Several legal reasons Grace Millane's killer continues to have name suppression. NZ Herald. Retrieved from https://www.nzherald.co.nz/ nz/news/article.cfm?c id=1\&objectid=12288193

Judicial proceedings (1934, July 7). Otago Daily Times, p. 12.

Local and General (1921a, February 2). Evening Post, p. 6.

Local and General (1921b, May 3). Evening Post, p. 6.

Local and General (1929, September 9). Evening Post. p. 4.

Not for publication (1920, December 21). Sun, p. 7.

NZ move to suppress accused's name (1975, April 24). Canberra Times, p. 2.

Quite pardonable difference (1925, November 28). NZ Truth, p. 3.

The courts today (1920, November 24). Evening Star, p. 7.

The Criminal Code Amendment Bill (1905, July 1). Lyttelton Times, p. 4. The 'hush-hush' policy (1920, October 27). Wairarapa Daily Times, p. 4 Very inadvisable (1920, October 22). New Zealand Times, p. 4. 


\section{References}

Ackland, R. (2018). Australia: A brief history of recent court suppression orders. Gazette of Law and Journalism. Retrieved from: https://inforrm.org/2018/12/30/australia-abrief-history-of-recent-court-suppression-orders-richard-ackland/

Barrett, J. (2012). Names suppression orders and Web 2.0 media: The New Zealand experience. European Journal of Law and Technology, 3(1), 1-10.

Brandwood, J. A. (2017). You say 'fair trial' and I say 'free press': British and American approaches to protecting defendants' rights in high profile trials. In E. Barendt (Ed.), Media freedom and contempt of court (pp. 1412-1451). New York, NY: Routledge.

Buckingham, D. (2011). Keeping justice blind online: suppression regimes and digital publishing, 12 Otago LR 557.

Canadian Judicial Council. (2007). The Canadian justice system and the media. Canada: Canadian Judicial Council.

Cheer, U. (2015). Burrows and Cheer: Media Law in New Zealand (7th ed.). Wellington, New Zealand: Lexis Nexis.

Crown Prosecution Service. (2018). Contempt of court, reporting restrictions and restrictions on public access to hearings. Retrieved from https://www.cps.gov.uk/ legal-guidance/contempt-court-reporting-restrictions-and-restrictions-public-accesshearings

Davis, C. (2001). The injustice of open justice, [Austlii online version]. Retrieved May 1, 2020, from http://www.austlii.edu.au/au/journals/JCULRev/2001/7.html

Eckersley, K. (2016). Name suppression until conviction: An argument in support of a return to s45B of the Criminal Justice Act 1954 (Unpublished LLB research paper, Victoria University of Wellington, New Zealand). Retrieved from https://researcharchive. vuw.ac.nz/xmlui/handle/10063/5223

Jones, K. (1995). The suppression discretion: Name suppression law in New Zealand (Unpublished LLB (Honours) dissertation), Victoria University of Wellington, New Zealand). Retrieved from http://researcharchive.vuw.ac.nz/handle/10063/7181

Judicial College. (2016). Reporting restrictions in the criminal courts April 2015 (revised May 2016). Retrieved May 1, 2020 from https:/www.judiciary.uk/wp-content/ uploads/2015/07/reporting-restrictions-guide-may-2016-2.pdf

Lazar, C. (2012). New Zealand's litigation-related name suppression policies: A workable model for the United States. University of Miami International and Comparative Law Review, 20(1). Retrieved from: https://repository.law.miami.edu/umiclr/vol20/iss1/4/

McLachlin, B. (2003). Courts, transparency and public confidence - to the better administration of justice. Deakin Law Review, 8, 1-11.

Metcalfe, K. (2018). Publication bans are hurting the national conversation. Canadian Journalists for Free Expression. Retrieved May 1, 2020 from: https:/www.cjfe.org/ publication_bans_are_hurting_the_national_conversation

Ministry of Justice. (2020). Justice Statistics data tables. Notes and trends for 2018/2019. Retrieved from: https://www.justice.govt.nz/justice-sector-policy/research-data/ justice-statistics/data-tables/

New Zealand Law Commission. (2008). Suppressing names and evidence. (Issues Paper 13). Retrieved from https://www.lawcom.govt.nz/sites/default/files/projectAvailableFormats/PDF.pdf

New Zealand Law Commission. (2009). Suppressing names and evidence, (Report 109). Retrieved from https:/www.lawcom.govt.nz/sites/default/files/projectAvailableFormats/NZLC\%20R109.pdf

Papers Past (2020). NZ Truth. Retrieved from https://paperspast.natlib.govt.nz/news- 
papers/nz-truth

Patel, S. (2018). Suppression orders - balancing individual and public interests. Retrieved from: https:/www.districtcourts.govt.nz/about-the-courts/j/suppression-ordersbalancing-individual-and-public-interests/

Pearson, M., \& Graham, C. (2010). Suppression orders: reskilling journalists and the judiciary. Australian Journalism Review, 32(1), 97-114.

Reihle, A. (1996) Canada's Barbie and Ken murder case: the death knell of publication bans. Indiana International and Comparative Law Review, 7(1), 193-222.

Stace, M. (1976). Name suppression and the Criminal Justice Amendment Act 1975. British Journal of Criminology, 16(4), 395-399.

Francine Tyler is a PhD candidate and teacher of media law and court reporting in the journalism school at Massey University, Wellington, New Zealand. She is a former court and crime reporter.

ftyler@massey.ac.nz

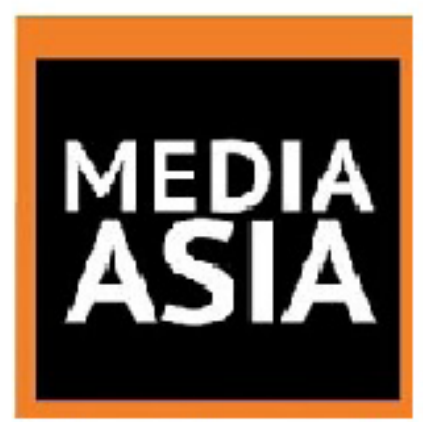

Faculty, students, media practitioners and researchers are invited to send their articles to Media Asia. It is a peer-reviewed quarterly journal published by the Asian Media and Information Communication Centre (AMIC) and Routledge Taylor \& Francis Group. Published since 1974, Media Asia is in its 46th year.

Papers should focus on practices in journalism, advertising, public relations, entertainment and other aspects of media.

For more information, please send an email to media.asia@amic.asia. 